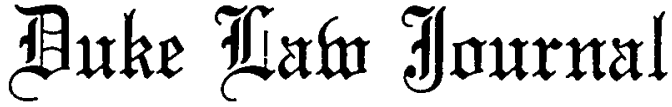

\section{TESTIMONIAL PRIVILEGES AND THE PREFERENCES OF FRIENDSHIP}

\author{
SANFORD LEVINSON*
}

Professor Levinson distinguishes two difficulties in the law of testimonial privilege. The first is that of identifying the core of concerns that the law of privilege is intended to address. The second is that of explaining how the structure of the positive law 'fits" these core concerns. Analysis of the first difficulty shows that privilege law imputes to intimacy a value that is not reducible to the individualistic concerns that underlie the privilege against self-incrimination. Discussion of the second difficulty reveals that the law evasively and unthinkingly has compromised the value it would-and ought to-accord to intimate relationships.

We are justly punished for those exclusive attachments which make us blind and unjust, and limit our universe to the persons we love. All the preferences of friendship are thefts committed agamst the human race and the fatherland. Men are all our brothers, they should all be our friends. ${ }^{1}$

J.-J. Rousseau.

\section{INTRODUCTION}

\section{A. Citizen Versus Friend.}

Rousseau's stateinent almost inevitably generates disquiet for anyone concerned about protecting soine notion of a "private" life against

* Professor of Law, University of Texas Law School. It is especially fitting that I thank the many friends who have leelped ine with this paper, including-but not limited to-Tiın Scanlon, Ellen Chances, Amy Gutmann, Paul Brest, Bill Powers, Bob Nozick, Rick Leinpert, Dennis Thompson, Sissela Bok, and Deborah Rhode. Versions of this essay were presented at Princeton University and the New York University, South Carolina, Buffalo, and Duke Law Schools. I ain grateful for coinunents received on those occasions. Special thanks go to iny civil liberties classes at Princeton University for their good-huinored, if disbelieving, reactions to these ideas.

1. J.-J. Rousseau, 4 Correspondence Generale 82 (1925), quoted in S. OK1N, Women in Western Political Thought 182-83 (1979). 
the encroachment of an all-embracing society, not to mention the allembracing State. One of the reasons given by those of Rousseau's detractors who view him as "totahtarian" is his unrelenting attack on the moral claims of all "partial" groups, including such primary groups as friends and family. Who, once having read the beginning of Emile, can ever forget the Spartan inother who berates the messenger for first telling her that her five sons have died before indicatimg that the Spartans mdeed had won the battle? ${ }^{2}$ That to Rousseau was what it meant to be a genuine citizen, fully socialized into the community.

Central to the liberal vision of society, though, is the contrary claim that one can be both "inan"-or "woman"-and "citizen."3 One need not, it is argued, be forced to choose between mamtaming private relationships, on the one hand, and, on the other, coinpletely effacing one's sense of a private realm by adopting a universalistic commitment to the strangers who constitute the State.

It is not only Rousseau who demands nuch of his citizens. Several recent critiques of utilitarianism focus on the same alleged universalism which pervades that doctrine, and many of these criticisms depend for their rhetorical effect on the almost self-evident pull of the "preferences of friendship." John Taurek thus answers his question, "Should the Numbers Count?"4 negatively by arguing that it is of course legitimate for a person to give his scarce dose of medicine to his best friend and save her life alone rather than give it to five others who, each needing a smaller dose, could be saved instead. Similarly, Charles Fried, in his book Right and Wrong, strongly condemns as almost hiterally inhuman any views that would require treating friends and strangers as having equal claim to our loyalties. ${ }^{5}$

2. J.-J. Rousseau, Emile OR ON EduCation 40 (A. Bloom trans. 1979). The view that Rousseau states finds its opposite in Camus's remark that "I believe in justice, but $I$ will defend my mother before justice," quoted in H. LotTMan, Albert Camus: A Blography 618 (1979).

3. See generally J. ShKLAR, MeN ANd Citizens 186-88 (1969).

4. Taurek, Should the Numbers Count? 6 PhIL. \& PUB. AfF. 293, 294-308 (1977). But see generally Parfit, Innumerate Ethics, 7 PHIL. \& Pub. AfF. 285 (1978).

5. C. Fried, RIGHT AND Wrong 36-37 (1978). See generally Kagan, Does Consequentialism Demand Too Much?-Recent Work on the Limits of Obligation, 13 PHIL. \& Pub. AFF. 239 (1984), which addresses the implication of consequentialist philosophies-such as utilitarianismthat

agents are morally required to make their largest possible contribution to the overall good-no matter what the sacrifice to theinselves might involve (remeinbering only that their own well-being counts too). There is no linit to the sacrifices that morality can require; and agents are never permitted to favor their own interests at the expense of the greater good.

Id. at 239. Noting that "[o]ur ordimary moral intuitions rebel at this picture," id., Kagan reviews several recent works that attempt to provide limits to the duties of morality without lapsing into an egotism that ultimately recognizes no moral duties at all. He argues that none of these efforts is adequate and concludes that "we inay have to face the sobering possibility that it is not conse- 
Fried is, moreover, unwilling to accept any utilitarian account that defends the preferences of friendship on the ground that they lead in fact to the optimal set of distributional consequences. Such a defense leaves open the possibility of limiting, or eliminating, such preferences should it turn out that they lead to less-than-optimal consequences. The very fact that utilitarianisni treats the status of friendship and private life as open to question counts for Fried as one of its fatal defects. A strongly individuahst, rights-based approach does not, he argues, share this problem. ${ }^{6}$

The claims of friendship are indeed soinetimes taken to commanding heights. Peter Berger has asserted, for example, that "if there is one universal, indeed primeval, principle of inorality, it is that one must not deliver one's friends to their enemies." 7 The overriding importance of the preferences of friendship was perhaps most famously expressed by E.M. Forster: "[I]f $\mathrm{I}$ had to choose between betraying my country and betraying iny friend I hope I should have the guts to betray iny country." 8 Forster's "notorious remark" was recalled by The Times of London in an editorial considering the saga of Anthony Blunt, a British subject who worked as a Soviet agent from the 1930's until the early 1950 's. Even after ceasing his work, Blunt apparently helped his friends

quentialism, but our intuition, that is in error." Id., at 254. See also Lichtenberg, Book Review, 92 Yale L.J. 544 (1983) (reviewing S. Scheffler, The Rejection of ConseQuentialism: A Philosophical Investigation of the Considerations UNDERLYing Rival Moral ConcepTIONS (1983), one of the books discussed by Kagan); Schiffrin, Liberalism, Radicalism, and Legal Scholarship, 30 UCLA L. REv. 1103, 1143-44 (1983).

6. But see L. Blum, Friendship, Altruism AND MORAlity 43-66 (1980). Blum points out that the Kantian approach, upon which much anti-utilitarian, rights-based analysis depends, strongly condemns "partial" action in precisely the ways suggested by Rousseau. Kantian ethics

condemns . . . benefiting one's friend simply because he is one's friend. . . . For such benefiting gives no guarantee of being justifiable froun an inpartial perspective; yet it is such a perspective which, on the Kantian view, morality requires. But friendship itself does at least appear morally condemned on this view, for it appears to be an integral part of what friendship is that we do often act for the sake of our friend's good simply because he is our friend, and without thinking that such action is or needs to be vindicated froin an impartial point of view.

Id. at 45. What Fried, like inost other contemporary rights theorists, does not do is offer either a persuasive philosophical groundwork or any real guidance as to the social meaning of the rights that in some sense we surely have. One can easily imagine a rights-based philosophy that states that we can never prefer our friends when doing so would violate the rights of other autonomous individuals, including those who are strangers to us.

7. Berger, Now, 'Boat People' From Taiwan?, New York Times, Feb. 14, 1978, at 35, col. 4.

8. E. M. Forster, Two Cheers For Democracy 66 (O. Stallybrass, ed. 1972). In fairness to Forster, one should note that he prefaces his remark by saymg, "I hate the idea of causes, and if I had to choose . . . There is therefore a deep anounaly in the citation of Forster by those who defend loyalty to comrades in political causes in the name of Forsterian notions of friendship, for Forster is deeply suspicious of all general social or political claims and not simply of those asserted by the State.

9. Mr. Robinson and Mr. Blunt, The Times (London), Nov. 22, 1979, at 15, col. 2. 
Guy Burgess and Donald Maclean to escape England and go to the Soviet Union. "When later I realized the true facts about Russia," said Blunt, "I was prevented from taking any action by personal loyalty; I could not denounce my friends." 10 The Times saw Forster standing behind Blunt and argued that the acceptance of such views "tend[s] to the destruction of those obsolute [sic] standards of loyalty on which a democratic society depends." 11

Forster, however, affirmed the importance of "personal relationships," which provided "a little order" apart from "the contemporary chaos. One must be fond of people and trust them if one is not to make a mess of life, and it is therefore essential that they should not let one down." Individual rehability is therefore essential. "But reliability is not a matter of contract-that is the maim difference between the world of personal relationships and the world of business relationships. It is a matter for the heart, which signs no documents."12

One vital purpose of the State is to create bonds of commitment among strangers - transformed imto "citizens"-and therefore, of necessity, to challenge the priority of the preferences of friendship. Yet only the perfectly socialized citizenry of Rousseau's vision of Sparta escapes the ceaseless tug-of-war between the loyalties of citizens and the loyalties of friends. Even Forster's critics, one suspects, would be repelled by a regime that imposed upon its citizens a duty to inform the authorities of any legally dubious acts of friends and family members. Our reaction today to such a regime could be expressed by the language used by Edward Livingston, in 1833, $\mathrm{m}$ regard to the continental rule that all such information be disclosed to the State:

[This] ferocious legislation [requires] a dereliction of every principle that gives dignity to man . ... If the father commit treason, the son nust abandon [the country] or deliver him up to the executioner. . . . [M]en are required to be faithless, treaclierous, unnatural and cruel, in order to prove that they are good citizens, and worthy members of society. ${ }^{13}$

10. Professor Blunt Tells How He Spied for Russia, The Times (London), Nov. 21, 1979, at 4, col. 3 (statement of Anthony Blunt).

11. Mr. Robinson and Mr. Blunt, supra note 9, at 15, col. 2.

12. E. M. FORSTER, supra note 8, at 66.

13. E. Livingston, A System of Penal Law for the State of Louisiana 14 (Philadelphia 1833), quoted in Franklin, The Encyclopediste Origin and Meaning of the Fifth Amendment, 15 LAW. GuILD REv. 41, 46 (1955), quosed in In re Agosto, 553 F. Supp. 1298, 1331 (D. Nev. 1983) (granting a son a privilege not to testify agaimst his father, a reputed participant in organized crime); see infra text accompanying notes 58-60; see also J. RAwLS, A THEORY OF JUSTICE 475 (1971): "[B]etrayal of friendships, and the like, are especially forbidden. The violation of these ties to particular individuals and groups arouses more intense moral feelings, and this entails that these offenses are worse [than violations of ordinary morality]." Professor Kandoian calls for recognition of a constitutional "right in the individual to place loyalty to a parent above loyalty to 
Only the Spartan, or the alienated member of a thoroughly iniquitous state, can avoid the conflict of loyalties and the consequent dilemmas of betrayal. In our own society-as opposed, perhaps, to the ancient polis-we are what might be termed "plural selves," torn between various social reference groups that serve as sources of personal identity and integrity. If the enemies of our friends were the enemies of all humanity, then of course there would be no problem. Life is not that simple.

The very recognition of conflict means that our competing identities and commitments cannot necessarily be placed into a neat rankorder whereby we might know, in any given situation, whicl particular relationship-whether that of family, friendship, or the State-sliould take priority over its conpetitors. Instead, as Michael Walzer notes, our relationships are all contingent and thus uncertain: "[A] pluralist, at bottom, is a man with more than one commitment, who inay at any moment have to choose among his different obligations." 14 Life is not only not snnple; its complexities are terrifying, for the brooding omnipresence of pluralism is betrayal, and the victims of one's own acts of betrayal may include not only one's friends but also the State, toward which one inevitably feels some measure of loyalty. Tlie resentment of the betrayed is not the only source of unease; to the extent that one's self is composed of the totality of one's commitments and relations, one's acts of betrayal erode one's very sense of self-identity.

Even the choice of citizenship over the pull of friendship may be received ambivalently by the very society that presumably benefits from the choice. Popular culture captures this ambivalence in a scene in John Ford's classic movie The Informer: A Britislı police officer disdainfully puslies with his walking stick the thirty-pound rewarditself so obviously reminiscent of the thirty pieces of silver given to the arch-betrayer Judas - toward Gypo Nolan, wlio has just conveyed the whereabouts of his friend and political comrade to the British enemy. It is as if the police officer were unwilling to risk the contamination that might arise from even an accidental touching of flesh by physically handing over the money. ${ }^{15}$ And, contrary to the certitude of The Times, many letters im the English press revealed at least some willingness to accept Blunt's arguments about friendship even as they denounced his decision to spy for the Soviet Union in the first place.

the state." Kandoian, The Parent-Child Privilege and the Parent-Child Crime: Observations on State v. DeLong and In re Agosto, 36 ME. L. Rev. 59, 61 (1984); see also infra note 46.

14. M. Walzer, Obligations 205 (1970).

15. See V. NAVASKy, Naming Names $x$ (1980). 


\section{B. Friendship Within the Law.}

This ambivalence, mirroring the internal conflict experienced by anyone having to choose between the demands of friendship and those of the wider society, is reflected as well in the legal structure of the liberal State. In its doctrines concerning testimonial privileges ${ }^{16}$ the American legal system recapitulates this antimomy of the public and the private. This article focuses on such privileges, for they serve to illuminate the problems that face any social order-or philosopherthat seeks some resolution of the antinomy other than the simple suppression of one of its ternns. Testimonial privileges are a rich field for inquiry because they represent an area of the law where the State in effect limits its own power by recognizing the contimuimg priority of pre-political personal relationships over the identification of oneself as a member of the political cominunity.

Indeed, the law in this area is necessarily implicated with some moral view about the claims of competing loyalties. ${ }^{17}$ But what differentiates the law from ordinary moral discourse is the connection of law with the imposition of organized public force. One may feel anguish when presented with any difficult choice, but surely it makes a difference to our analysis that the consequence of choosing loyalty to a friend over obedience to the State is not only the State's opprobrium, but also the loss of one's own freedom. That is the predicament that faces the person who risks being held in legal contempt for refusing to disclose information that would betray his or her relationship with the target of the State's inquiries.

This article is an attempt to expose the underpinnings of the law of testimonial privilege. Although I shall throughout the article mention and analyze various cases involving the freedoin not to testify, especially where the assertion of that freedom is predicated upon the preferences of friendship, I do not pretend to be stating either a constitutional theory ${ }^{18}$ or a theory belonging to the positive law of evidence. Thc decided cases are valuable not so much for their doctrine as for the

16. "Testimonial privileges" here refer to the entitlements held by various individuals under various circumstances to refuse to testify, or to prevent others from testifying, before agencies of the State. Although niost of the privileges that will be discussed below are accompanied by a general duty of confidentiality vis-a-vis the public, I am not, in this article, interested in a general theory of confidentiality. Instead, I an focusing only on the self-denial on the part of the State regarding information about natters of public import that it would both wish and, in the absence of the privilege, be able to have.

17. See Krattenmaker, Interpersonal Testimonial Privileges Under the Federal Rules of Evidence: A Suggested Approach, 64 GEo. L.J. 613, 647-68 (1976).

18. For a discussion of the constitutional dimension of the protection of intinacy, see Karst, The Freedom of Intimate Association, 89 Y ALE L.J. 624 (1980). 
concrete and often wrenching examples they present. I shall also describe at least one fairly elaborate hypothetical example, or "thought experiment," of the sort often encountered im philosophical discussions.

This article does not pretend to make an imdependent contribution to moral philosophy, but the thought experiment will be useful in placmg received doctrine within a perspective of conceivable alternatives. The abstractions of doctrine allow us to congratulate ourselves for having proper values, such as "privacy" and "friendship," but the depth of our commitment to such values has to be tested against examples provided both by everyday life and by philosophical imagination. This essay will have achieved its purpose if it leads the reader to a greater appreciation of the degree to which the positive law of testimonial privilege represents an unstable and largely unthinking attempt to reconcile values we proudly expound with others whose influence we acknowledge less readily.

\section{The Problem of Theory}

\section{A. The Self and its Agents.}

All testimonial privileges block the State from coinpelling the disclosure of information that would presumably aid it in achieving knowledge of the truth about matters of public importance. Such failures of disclosure nay also, of course, lead to injustice. Nonetheless, privileges are among the most important unarkers our society offers to adumbrate that there are nore important values than truth and justice.

The most famous privilege in our legal system is the fifth-amendment privilege against coinpulsory self-incrimination. Its partisans include among their justifications its role in signifying to the society at large a respect for the integrity of the individual; it is thought unseemly to require a person to be the agent of her own destruction. ${ }^{19}$ Other, more imstrumental, defenses are also available; one inight emphasize, for example, the role of the privilege in deterring torture and other unacceptable investigatory practices. Moreover, one might well fear that such practices generate unreliable evidence, as individuals confess to crimes in order to avoid further coercion, whether physical or psycliological. However, the instrumental defense of the fifth amendment both is logically separable front the "humnan dignity" defense and can lead to significantly different outcomes. Consider, for example, the rationale for allowing the accused to remain silent even in the courtroon. Here, the witness is protected both by his lawyer and by the judge fron1

19. See, e.g., Brown v. Walker, 161 U.S. 591,637 (1896) (Field, J., dissenting); E. GRISwOLD, THE FIFTH AMENDMENT TODAY 7-10 (1955). 
unseemly pressure. Only the "human dignity" rationale can be plausibly offered in justification. If, on the other hand, one's concerns are primarily imstrumental, there is almost no good reason to extend the fifth amendment privilege to the courtroom itself.

One appealing way of conceptualizing a number of the testinonial privileges is within a fifth amendment framework. One might wish to protect communications between a person and her lawyer or psychiatrist on the ground that the other person is in reality merely an agent of the central self and should therefore be accorded the amendment's protection. We realize that the shoals and eddies of nodern life cannot be navigated without the employment of agents, and protecting the intercourse between self and at least some agents may be implied by the command of the amendment that the mdividual be protected agamst self-mcrimination. In talking to one's lawyer or psychiatrist, one is, in soine sense, communicating with "oneself." Just as the State cannot delve into our minds to reconstruct internal conversations and memories, at least when such reports would be imcriminating, so it might be argued that the State cannot examme communications between selves and agents. ${ }^{20}$

This einphasis on agency also helps to explaim the specific nature of most of the testimonial privileges. We are entitled to confidentiality when talking to our doctor qua medical agent or our lawyer qua legal advisor. There is no notion at all that our relationships with these agents are "intimate" im any important sense, only that they are necessary to effective protection of our selves, whether defined physically or legally. ${ }^{21}$

An agency theory of the "relation protecting" privileges accords with the essentially Hobbesian background of the fifth amendment. If the individual enters society, he does so with foreboding and retains maximal freedom of self-protection. There is no meanimgful sense of socialization; obligations to society, mcluding the necessity to testify to one's misdeeds, take second place to self-protection. "In such a world,"

20. Among other problems with an analysis along fifth amendment lines, lowever, is the problem that the legal status of self-communication such as entries im personal diaries is scarcely clear. See, e.g., Fisher v. United States, 425 U.S. 391, 401 n.7 (1976) ("Special problems of privacy . . . might be presented by subpoena of a personal diary. . . ."); United States v. Bennett, 409 F.2d 888, 897 (2d Cir. 1969) (Friendly, J.); $c f$. United States v. Doe, 104 S.Ct. 1237, 1245 (1984) (O'Connor, J., concurring) ("I write separately . . . just to make explicit what is implicit in [Justice Powell's opmion for the Court]: that the Fifth Amendment provides absolutely no protection for the contents of private papers of any kind.").

21. Such an emphasis on self-protection also explains why it is that psychiatric exchange with a programmed computer would probably be protected against discovery by the Statc, even though it would confound ordinary discourse to speak of an "mtimate relationship" between an individual and his computer. 
as Mark Tushnet puts it, "people exist as isolated islands of individuality who choose to enter into relations that can metaphorically be characterized as foreign affairs." 22 To this day, few persons seem seriously to doubt the legitimacy of national self-preference, includimg keeping important information secret and, indeed, lymg when that is in the national interest. Hobbes simply endowed everyone in the state of nature with the same rights we accord to nation-states; the fifth amendment's guarantees have the same Hobbesian, self-protective cast.

One should not over-emphasize the extent to which the fifth amendment is genuinely "privacy" oriented. Positive constitutional law allows the withdrawal by the State of one's fifth-amendment rights following a grant of immunity from prosecution. ${ }^{23}$ Were the fifth amendment truly a protection of privacy, the immunity grants would be prohibited, given that the "beneficiary" of such grants is forced to testify about inatters that he might well prefer to keep private. The privileges that protect our relationships with doctors, lawyers, and spouses, however, may not be overridden by immunity grants. This asymmetry between the self-protecting fifth aniendinent privilege and the traditional relation-protecting privileges suggests that the value of privacy is significantly more central to the latter category of privilege than to the former. Thus it makes hittle sense to attempt to derive the relation-protectimg privileges froin the fifth amendment.

It could be argued that the protections accorded relationships with doctors or lawyers show, not a strong commitment to privacy per se, but a basically utilitarian judgment that society benefits fron maximum disclosure to selected professionals. The professional serves as agent of the self but society is his ultimate master. This may, in fact, be the most plausible view of the privileges that involve professionals, but there is something distinctly odd about viewing the central testimonial privilege - that of spouses - within the framework of the agency relationship. Intimates are different from agents; moreover, the rationale for protecting intimate relationships may be quite different from that for protecting the self and its agents.

This difference between self-protection and relationship-protection is importantly slighted by Charles Fried, who is one of the major participants in the contemporary conversation about the meaning of privacy. Having earlier asserted the central importance of privacy to

22. Tushnet, Following the Rules Laid Down: $A$ Critique of Interpretivism and Neutral Principles, 96 HARV. L. Rev. 781, 783 (1983).

23. See Ullmann v. United States, 350 U.S. 422, 430-31 (1956); Brown v. Walker, 161 U.S. 591,594 (1896). 
making possible friendship and love, ${ }^{24}$ Fried has gone on to defend the legitimacy of the lawyer's commitment to a client, including the duty to preserve clients' confidences, by comparing the lawyer to a friend. ${ }^{25}$ To be sure, the lawyer is not exactly like one's closest friends. But he is at least a

limited-purpose friend. A lawyer is a friend in regard to the legal systein. He is someone who enters into a personal relation with you. ... That means that like a friend he acts in your interests, not his own; or rather he adopts your interests as his own. I would call that the classic definition of friendship. ${ }^{26}$

This is a thoroughly dubious definition of friendship. It defines the friend exactly as one would define an agent-an extension of one's own self for one's own purpose. At the very least, one would think that persons would choose their friends on the basis of soine notion of shared values. Plato, for example, captured one "classic" notion of friendship when he suggested that one can make a "true friend" only of a person "of the same character, who agrees with [one's] tastes and dislikes." 27 The world of Greek antiquity was one almost wholly different from our own, with its emphasis on atomized selves "each guided by his or her own idiosyncratic values and goals." 28 The lawyer or doctor, of course, im neither theory nor often in fact chooses clients on the basis of judgment as to similarity of character.

Indeed, the problems with Fried's argument by analogy are highlighted once one realizes that positive law entitles friends, as such, to awesomely little protection against the inquisitiveness of the State. If the lawyer were "inerely" a friend, Fried's argument would collapse in spades, unless he then went on to assert the desirability or moral necessity of according friends the same protections (and duties) as lawyers. He does not do this. He could establish a better legal symmetry were he to refer to "the lawyer as spouse," but that would obviously serve only to emphasize the fallacy of his overall arguinent. ${ }^{29}$

24. See Fried, Privacy, 77 YAle L.J. 475, 477 (1968).

25. See generally Fried, The Lawyer as Friend: The Moral Foundations of the Lawyer-Client Relation, 85 YALE L.J. 1060 (1976).

26. Id. at 1071 .

27. Plato, Gorgias *510c; see also A. Macintyre, After Virtue 114-53 (1981) (discussing the importance of shared values to Greek philosophy).

28. Tushnet, supra note 22, at 783.

29. See Modern Woodınen v. Watkins, 132 F.2d 352, 354 (5th Cir. 1942) (attorney-client privilege not available when lawyer was consulted "merely as a personal friend"), cited in Goodc \& Sharlot, Article V: Privileges, 20 Hous. L. Rev. 273, 288 n.63 (1983); see also Dauer \& Leff, Correspondence: The Lawyer as Friend, 86 YALE L.J. 573 (1977). For a similar result in regard to a clergyinan, see Burger v. State, 238 Ga. 171, 172, 231 S.E.2d 769, 771 (1977) (statements to witness were not inade by way of "professing religious faith or seeking spiritual comfort" or 
There is one further danger in einphasizing the fifth ainendinent as the philosophic source of the testimonial privileges: in the real world there is inevitably what might be termed "hydraulic pressure" to justify the gathering of evidence against alleged wrongdoers. That is, if we cannot ask them directly if they committed a given act, then we must ask their friends or infiltrate their hives with informers. ${ }^{30}$ Although it is perfectly logical to oppose all of these practices, law is, as we are told, the product of experience rather than abstract logic. One inay simply be forced to choose, however reluctantly, between what I ain calling the values of self-protection and those of relationship-protection. And I should confess that my own view is that friendship and love are values eminently worth protecting, while protection of the isolated self, concerned only with maximizing individual satisfactions, is nuch less worthy.

We should therefore recognize that defenses of testimonial privileges must clearly separate those theories based on protecting the individual self from those that emphasize instead the importance of protecting relationships. It is only fair to note that even this latter conception does inply a notion of individual selfhood, to be sure, but one that emphasizes the self as importantly social. ${ }^{31}$ Such a self gets its ultimate meaning from what might be termed dialectical interaction rather than mere "exchanges" between radically separated "individuals." Even as we recognize the ineluctable role of personal interest, at some point the separate interests of the parties are molded in the creation of a new entity - the friendship, affair, marriage, or whatever. Individuals become transformed insofar as they join in relationship with others and tame at least some of the passions of the covetous Hobbesian self. Under these circumstances, one can indeed einbrace Fried's "classical" definition of friendship, as both parties seek the interests of the other, but there is an obvious reciprocity here that distinguishes the case from the hierarchy typified in the agency relationship.

\section{B. Taking Relationships Seriously.}

Once it has been inade clear that the privileges that shield relationships are not reducible to the fifth amendment protection accorded to

'guidance,' but were conversational statements to [one who was a] friend and frequent companion. ....").

30. See Levinson, Under Cover: The Hidden Costs of Infiliration, The Hastings Center

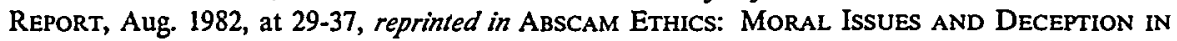
LAW ENFORCEMENT 43-64 (G. Caplan ed. 1983).

31. See M. SANdel, Liberalism and the Limits of Justice 62-65 (1982), which, in contrast to traditional liberahism, emphasizes the constitutive role of community membership in defining what it means to be a genume self. 
the self, it remams debatable whether the several relation-protecting privileges can be defended and explaimed by reference to some common feature. The Supreme Court, in Trammel $v$. United States, ${ }^{32}$ suggested that the classical privileges "are rooted in the imperative need for confidence and trust." 33 The Court described the marital relationship as "the best solace of human existence" 34 and contimued:

The priest-penitent privilege recognizes the hunan need to disclose to a spiritual counselor, in total and absolute confidence, what are believed to be fiawed acts or thoughts, and to receive priestly consolation and guidance in return. The lawyer-client privilege rests on the need for the advocate and counselor to know all that relates to the chent's reasons for seeking representation if the professional mission is to be carried out. Similarly, the physician inust know all that a patient can articulate $\mathrm{m}$ order to identify and to treat disease; barriers to full disclosure would impair diagnosis and treatment. ${ }^{35}$

The Trammel Court, however, left the crucial question unanswered: whose conception of "need" controls? Does society honor those conceptions of individual "need" held by its members, regardless of the cost to important general policy goals? As Ronald Dworkin has argued so insistently, this indeed is what it means to take a right seriously. ${ }^{36}$ Or, on the contrary, is "need" to be defined by society itself, so that it decides what is socially useful and then structures a regime of privileges accordingly?

This latter, sociocentric justification is at the leart of Dean Wigmore's classic presentation of the circumstances under which a privilege slould be recognized in law:

(1) The communications inust originate in a confidcnce that they will not be disclosed; (2) This element of confidentiality must be essential to the full and satisfactory maintenance of the relation between the parties; (3) The relation nust be one which in the opinion of the community ought to be sedulously fostered; and (4) The injury that would inure to the relation by the disclosure of the communications must be greater than the benefit thereby gained for the correct disposal of litigation. ${ }^{37}$

32. 445 U.S. 40 (1980).

33. Id. at 51 .

34. $I d$.

35. Id. (quoting Stein v. Bowman, 38 U.S. (13 Pet.) 209, 213 (1839)).

36. See R. Dworkin, TAKING Rights Seriously 82-94 (1977). I should make clear that my citation to Dworkin and discussion of rights in the text does not mean that $I$ necessarily take rights seriously. Nonetheless, insofar as any reader of this essay professes to take rights seriously, I think it will prove useful to consider the ramifications of such a position for the issue of testimonial privileges.

37. $8 \mathrm{~J}$. Wigmore, TREATISE ON Evidence $§ 2285$ (J. McNaughton ed. 1961) (emphasis in original). See generally R. LEMPERT \& S. SALTZBURG, A MODERN APPROACH TO EvideNCE 60615 (1977). 
This is not a conception that takes rights seriously, for individuals have only those privileges that the society itself deems desirable in order to attain broad social goals. Should society at large decide that the costs of a privilege outweigh its benefits, then presumably it will be withdrawn. Thus we have the potential paradox of society's supporting "the imperative need for confidence and trust" only so long as that support is useful; should it be socially counterproductive, it can be eliminated, unless one roots at least some privileges in some other, nonutilitarian conception of the self in its relation to the social order.

It is fitting that recent scholarly analysis of testimonial privileges has emphasized the notion of "privacy." Relying on an important article by Charles Fried, Professor Krattenmaker has noted that

[p]rivacy permits people to share intimacies and ideas upon their own terms, and thus to establish those mutual reciprocal relinquishments of the self that underlie the relations of love, friendship, and trust. . . . The ability to shield ourselves from public view permits the exchange of intimate confidences necessary to establish a secure love or trust. ${ }^{38}$

This is a conception of privacy that stands apart both from the calculating Hobbesian self and from calculating utilitarian society. One of the aims of this essay is to suggest that a genuine commitunent to the values of friendship and private life will require significant changes in the way we defend and explain, or explain and reject, the traditional testimonial privileges.

\section{The Problems of "Fit"}

\section{A. "Fit" and Status.}

However one prefers to justify the institution of testimomal privilege, viewed in the abstract, a more acute problein is to try to achieve

38. Krattenmaker, supra note 17, at 651 (citing Fried, Privacy, 77 YALE L.J. 475 (1968)); see also Wasserstrom, Privacy: Some Arguments and Assumptions, in PhILosopHICAL Law 148-66 (R. Bronaugh ed. 1978); Rieman, Privacy, Intimacy, and Personhood, 6 PHIL. \& PUB. AfF. 26 (1976). The most comprehensive review of the now massive literature on privacy is Gavison, Privacy and the Limits of Law, 89 Y ALE L.J. 421 (1980). This last article is especially helpful insofar as it focuses, unlike most purely philosophical exammations of the concept of privacy, on the cogency of looking to the legal system for aid in protecting privacy.

One should note, incidentally, that the kind of privacy protection discussed in the present article is different from the "right to privacy" that the State protects by preventing a psychiatrist, for example, froin publishing a book disclosing a patient's secrets. See, e.g., Roe v. Doe, 34 N.Y.2d 562, 354 N.Y.S.2d 941, 310 N.E.2d 539 (1974), cert. dismissed as improvidently granted, 420 U.S. 307 (1975). In this latter sort of case, the State is merely arbitrating a dispute between two private individuals. Although inportant questions of theory are involved, to be sure, there is not the ultimate drama of the State's denying itself information it would prefer to have in order to achieve some legitimate public purpose, such as the discovery and punishment of criminal behavior. 
some "fit" between the interests the positive law deems worthy of protection and the specific relationships that the classical privileges benefit. Whatever the underlying philosophical base, does the particular structure of privileges we have present a coherent whole?39 Or, on the contrary, does a yearning for analytical clarity lead to a rejection of the status quo, whether we are then driven toward either expansion or limitation of the existing privileges?

The problein of "fit" is not only a challenge to our desire for clarity, it is also an occasion to investigate the perhaps hidden cultural sigmificance of our existing scheme of privileges. As the structuralists have pointed out, any linguistic utterance depends for its meaning on the background of alternatives within the language..$^{40} \mathrm{We}$ learn what " $A$ " ineans only by comparing $A s$ with conceivable non- $A$ s. Thus the cultural meaning of the availability of testimomal privileges within a given legal order-and their alleged status as recognitions of the importance of maintaining private refuges against public intervention-can be fully grasped only if we "read" those privileges agamst the background of what is not protected. Focus on areas of personal space protected by privileges inay be misleading if we do not at the saine time take full cognizance of those areas where the State is unfettered in its legal abihty to seek information from its citizens.

Consider a standard context within which a testimonial privilege is invoked. Wives do not have to divulge intimate conversations with husbands, or vice versa, even if society would benefit thereby. There are probably few opponents of Richard Nixon's exaggerated claims of "executive privilege" 41 who would not have acquiesced had the situation involved instead specific conversations with Patricia Nixon in which he told her-and only her-what "really" happened. Not even a warrant, which, assuming probable cause, would suffice to allow the police entry into the bedrooin in order to search for incriminating tangible evidence, could authorize the State to compel a wife to testify to her husband's confidential whisperings. Indeed, the State could have

39. One might challenge the very notion that we should seek coherence in this area. Justice Jackson spoke of "a system which is justified, if at all, by accuunulated judicial experience, rather than abstract logic." Michelson v. United States, 335 U.S. 469, 487 (1948) (cmphasis added).

40. "[C]oncepts are purely differential, not positively defined by their content but negatively defined by their relations with other terms of the system. Their most precise characteristic is that they are what the others are not." F. DE SAUSSURE, Course in General Linguistics 117 (W. Baskin trans. 1959), quoted in J. Culler, Ferdinand De Saussure 18 (1976). As Culler goes on immediately to say, "Brown is what is not red, black, grey, yellow, etc., and the same holds for each of the other signifieds [i.e., what is being referred to by signifiers such as words]." See generally J. Culler, Structuralist Poetics: Structuralism, Linguistics, and the Study of LITERATURE 3-31 (1975).

41. See United States v. Nixon, 418 U.S. 683, 703 (1974). 
been barred from using even voluntary disclosures of confidential conversations, because her husband could have interposed his privilege to prevent such testimony.42 And this interposition would have been allowed even had Mrs. Nixon already published memoirs revealing her husband's secrets. ${ }^{43}$

The point I wish to raise, which concerns the debatable structure of our privilege law, can be inade most easily by the following question: If we are so willing to recognize the importance of intimate relationships when they are spousal, why not recognize them in other contexts as well, such as those between lovers, friends, or family? One may have a panoply of privileges in regard to one's spouse but have no legally recognized privilege concerning one's lover. ${ }^{44}$ In the latter context one can be compelled on pain of jail not merely to testify adversely but also to divulge the most intimate conversations. $A$ and $B$ are protected only if they enjoy the legal status of husband and wife. The private structure of intimacy must take the specific legal一and therefore public-form of marriage if it is to be safeguarded against public intervention. In no serious sense does the State give free rem to its citizens in choosing their own preferred structures of intimacy, for only onemarriage-receives the State's blessing.

Indeed, it is not only the lover who is unprotected in American law. Family relationships other than the spousal are generally not recognized as conferring testimonial privilege, ${ }^{45}$ altlough several courts have recently recognized a parent-child privilege. ${ }^{46}$ There is no doubt, thougl, that American law does not recognize a sibling privilege, let alone other kinship privileges. Friendship per se goes wholly unprotected.

Other testimonial privileges are similarly linked by the State to specific status. A person may liave a privileged relationship with his psychiatrist, but not with his psychologically astute close friend or colleague. One is protected against the forced (or perhaps even voluntary) betrayal by one's minister, but there is probably no protection at all

42. 8 J. WIGMORE supra note 37 , at $\S 2340(1)$.

43. Id. at $\$ 2339(3)$.

44. Id. at $\$ 2335(1)$.

45. Id. at $\S \S 2285,2286,2335$.

46. See Kandoian, supra note 13, at 60. But see State v. DeLong, 456 A.2d 877, 883 (Me. 1983) (upholding a seven-day sentence for criminal contempt by a fifteen-year-old girl who refused to testify against her adoptive father charged with sexually abusing her); Parents Ordered to Testify Against Son, Austin American-Statesman, June 19, 1984, at B2, col. 3 (parents must testify before grand jury regarding teen-age son accused of murder despite parents' claims that such testimony would violate their religious beliefs and "devastate [their] family unit"); Girl Held in Contempt, New York Times, Jan. 8, 1984, at 18, col. 1 (twelve-year-old girl placed in isolation in a Cahformia juvenile hall for refusing to testify agamst her stepfather, accused of molesting her). 
against the State's demand that a professor of philosophy inform it of what a student said while seeking advice about a profound ethical dilemma, such as the legitimacy of violence against a State waging an unjust war. ${ }^{47}$ The State, then, offers close to absolute protection against some incursions, even at the cost of at least short-run social utility, while it offers no protection at all against the many other potential incursions into the territories of the private self and its structures of mitimacy. 48

All of the present privileges are distinctly role-related. An individual is protected agamst disclosure of confidential conversations with other persons of defined roles: spouses, doctors, priests, and lawyers, for example. What joins all except the first, of course, is that they share the social status of being professionals. Indeed, insofar as claims are made to add to the present hist of privileges, they are almost inevitably linked to specific professional groups which claim to exercise functions similar to those of the already recognized professions. The title of a student note in the Yale Law Journal is illuminating: "Functional Overlap Between the Lawyer and Other Professionals: Its Implications for the Privileged Communications Doctrine."49

Law reviews and professional journals are filled with articles asserting such role- and status-related protections for other claimants, such as clinical psychologists, marriage counselors, social workers, and high-school guidance counselors. If they agree on hittle else, nost such articles join in asserting that protection depends on the presence of identifying markers, usually graduate degrees and/or state certification. And all these supplicants for testimonial privilege adopt what I have termed the "agency" theory of protection. Today's individual, it is

47. See In re Verplank, 329 F. Supp. 433, $436-37$ (C.D. Cal. 1971) (Presbyterian minister engaged in draft counselling unsuccessfully claiming a counselor-counselee privilege in addition to a clergyman-communicant privilege).

48. I find it relevant to compare the "fit" problem with those situations in which the State spends large sums of money to rescue "the child in the well" while ignoring the less dramatic, though far more pervasive, suffering that inight be averted by expending the money elsewhere. See G. Calabresi \& P. Bobbitt, Tragic Choices 131 -46 (1978); C. Fried, AN Anatomy of VALuEs 207-36 (1978). Those who defend the costly rescue often do so by reference to the symbolic importance of affirming the incalculable value of human life, even as they admit-perhaps only privately - that society by no means refuses to calculate and indicates thereby that some lives are in fact worth more than others. Some, less charitable, nnay view the rescue as simply a means by which the social order sentimentally pretends to adhere to values it has in fact rejected, howevcr much it prefers to deny this. One cannot even begin to answer such ideologically charged questions without attempting to develop some criteria for distinguishing on a colierent basis those situations in which we intervene from those in which we avert our eyes or otherwise change the topic of conversation. Similar problems confront anyone seeking to niake sense of our present sclieme of testimonial privileges.

49. 71 YALE L.J. 1226 (1962). 
claimed, needs not only to consult doctors, lawyers, and priests, but also to take advantage of the special skills of accountants, gurus, and others. ${ }^{50}$

Even if we adopt agency claims in regard, for example, to psychiatrists, surely the "fit" is highly imperfect. Why exactly should only the M.D.-holding psychiatrist or, in some states, the $\mathrm{Ph}$.D.-certified clinical psychologist be protected as one's agent, but not one's sensitive colleague who is willing to listen and to respond helpfully to one's troubles? That person must lie or go to jail if disclosure of intimate material is to be avoided. ${ }^{51}$

One of the things we see in the development of testimonial privileges through time is our capitulation to professionalism-the law serves as a cultural signal that the only persons, other than one's spouse, with whoin it is "safe" to speak about intimate matters are those with professional credentials. Professional status is thus essential to the invocation of most privileges; only professionals can genumely promise their clients whatever protection is given by the relevant privilege. Ordmary men and women have no legal protections to offer those who confide in them. Indeed, even those who have the relevant professional status do not, when speaking - or, more to the point, listening"as friends," enjoy a testimonial privilege. Thus, far fronı being evidence of a general commitment to the values of trust and privacy, the present systen of testimonial privileges is a symbol much more of our cultural over-commitment to the values of professionalism. Indeed, the present scheine of privileges actually denigrates the general importance of private intimate relationships.

\section{B. Status and Ease of Identification.}

The emphasis on status and credentials serves two functions. First, it adds social support to the claims of importance made by the protected professions. A way of indicatimg that a new profession has "arrived" is to give it access to testimonial privileges enjoyed by the

50. See, e.g., Brushwood, Is There a Pharmacist-Patient Privilege?, 12 LAw, MEd. \& Health CARe 63 (1984); Cross, Privileged Communications Between Participants in Group Psychotherapy, 1970 LAw \& THE SOC. ORD. 191; Robinson, Testimonial Privilege and the School Guidance Counselor, 25 SYRACUSE L. REv. 911 (1974); Comment, Underprivileged Communications: Extension of the Psychotherapist-Patient Privilege to Patients of Psychiatric Social Workers, 61 CAL. L. REv. 1050 (1973). Even though Cross recommends the extension of a testimomal privilege to lay members of therapy groups, his argument depends on the supervision of such groups by professional psychiatrists. There is no suggestion, for example, that ordimary friendships, surely more pervasive even than therapy groups, be protected.

51. See R. Harris, Freedom SPENT 315-435 (1976) (two friends go to jail rather than testify before a grand jury about one another). 
traditional professions of law and medicine. But there is a second function as well: Emphasis on credentials makes it possible to identify the specific individuals entitled to hold themselves out as enjoying the privilege. That is, even if in theory we might agree that sensitive coworkers should be allowed to claim the same privilege as psychiatrists, we are wary of identifying the category of "sensitive co-worker." The transaction costs of identification would be far too high to commend adoption of such a privilege by any society even mimimally committed to efficiency.

The problem is even more extreme in regard to friendship or love. Consider, for example, the suggestion of Professor Krattenmaker that "an interpersonal communication should be presumptively privileged if it was expressed im confidence and passed between mdividuals imtimately related or im a position of close personal trust."s2 One is immediately struck by the problem of verifying claims by a reluctant witness that he or she is an individual "mtimately related or in a position of close personal trust" to the person who would be affected by the testimony. Any identification tests would themselves be invasions of the private areas of intimacy one presumably wants to protect. The cure would be as bad as the disease if the method of proving "close friendship" were the duty to answer such questions as "Have you slept with $X$; have you told $X$ things you've told no one else (give examples) ...."

The marital privilege is a paradigm of easy identifiability. There are relatively unambiguous legal tests to determine who is married and who is not; if one passes those tests, the privilege holds. There is a similar ease in identifying those who are lawyers or doctors, even though the latter group introduces the world of the unconventionalthe chiropractor, herbahist, or practitioner of acupuncture. When we reach the rehigious minister, chaos ensues. It was easy enough to decide who was a priest so long as the Roman Catholic Church maintained its hegemony, but Protestantism of course opened the dikes. If one accepts the priesthood of all behevers, then is every believer entitled to the priest-peintent privilege?53 ${ }^{53}$ The answer, legally speaking, is obviously

52. Krattenmaker, supra note 17 , at 664 .

53. See Kuhlmann, Communications to Clergymen-When Are They Privileged?, 2 VAL. U.L. REv. 265, 289-90 (1968). It is also vital to decide who holds the privilege-the defendant or the member of the clergy-as illustrated by a New York Times article detailing the decision of a New York court permitting a rabbi voluntarily to testify about a murder confession, although the defendant invoked New York's law disallowing the disclosure of a confession "made to a [member of the clergy] in his professional character as spiritual adviser." The rabbi, a professor of Talmudic law, noted: "There is no priest-penitent relationship in Judaisn." This was echoed by another scholar, who stated that rabbis are not viewed as mediators between the laity and God. 
"No," although the theoretical difficulties remain. Deciding who is entitled to invoke that privilege causes scarcely less difficulty than deciding who was entitled to conscientious objector status under the statutory requirement of belief in a Supreme Being. ${ }^{54}$

It was almost undoubtedly this difficulty-secure and unambiguous identification of protected individuals-that contributed to the Supreme Court's refusal to extend the testimonial privilege to newspersons in Branzburg v. Hayes. ${ }^{55}$ How does one decide who is a reporter? Would a citizen-pamphleteer, perhaps inspired by I. F. Stone, be entitled to claim the privilege, or would a job with the New York Times or some other estabhished news organization be required? Perhaps the state could license reporters in the same way it licenses marriages. That inight make the newsperson's privilege administrable, but I suspect that we are rightly dubious about the merits of such a suggestion-even assuming its constitutionality under the first ainendment. ${ }^{56}$

\section{Ease of Identifiability and the Value of Intimacy.}

The focus upon ready identifiability seems unjustifiably to elevate the marital relation above otler intimate relations. Whatever the enthusiasm of the United States Supreme Court, among others, for the marital state, there is surely nothing unique about the ability of marital relationships to provide emotional and other succor. Many marriages are einotionally sterile, and deeper einotional intiniacy is often found among nonspouses. There may even be a touch of sexism linked to the emphasis on spousal status, for some researcli indicates that women are much more likely than men to confide intimate matters to close friends of the same gender. ${ }^{57}$ Men, who seem to confide, if at all, only in their wives, may be relatively better protected by the spousal privilege than

See Fried, Court to Allow a Rabbi to Testify on Alleged Confession in Slaying, N.Y. Times, May 9, 1980 , at B5, col. 1 .

54. See, e.g., Welsh v. United States, 398 U.S. 333, 338-44 (1970) (plurality opinion); United States v. Seeger, 380 U.S. 163, 166-69 (1965); see also Note, Toward a Constitutional Definition of Religion, 91 HaRv. L. REv. 1056, 1063-66 (1978).

55. 408 U.S. 665, 667 (1972). But cf. Silkwood v. Kerr-McGee Corp., 563 F.2d 433, 436-37 (10th Cir. 1977) (mdependent film maker held entitled to quakfied "newsman's confidentialsource" privilege).

56. Cf. First Nat'l Bank v. Bellotti, 435 U.S. 765, $797-802$ (1978) (Burger, C.J., concurring) (discussing whether first amendment confers special rights on the press establishment). One night also note, incidentally, the impossibility of treating the reporter as either agent or intimate; the only basis of recognizing a reporter's privilege is instrumental or utilitarian. See Dworkin, Is the Press Losing the First Amendment?, N.Y. Rev. of Books, Dec. 4, 1980, at 49.

57. See M. Komarovsky, Blue-Collar Marriage 205-19 (1967). "Women have more friendslips (as distinct from collegial relationships or workmates) than men, and the difference in the content and quality of their friendships is marked and unmistakable." L. RuBIN, INTIMATE STRANGERS 129 (1983). Friendship among women has also been the subject of increasing histori- 
their wives who have confided as well, or perhaps only, in their friends. An increasing number of people, noreover, have no desire to seek the State's blessimg for a voluntary union, while others, ironically, would like to enter the state of legal matrimony but are barred from doing so because their intended spouses are of the saine sex.

If one takes seriously the notion of private life honoring the "preferences of friendship," then it is necessary to expand the circle of protected relationships well beyond the marital arrangement and to accord lovers and friends the same protection as spouses. Anything less means simply that the professed regard for intimacy and trust is questionable. Just as the professional privileges can be interpreted at least in significant measure as a social means of shoring up the status of professionals, the spousal privilege can be interpreted as an effort to support a bourgeois notion of elnotional monogamy. Whatever one's views about sexual inonogainy, that is certainly a different issue from the protection of more general privacy and intimacy. The spousal privilege can be defended in teruns of the latter values only if one is willing to assert the justifiability of the State's limiting one's deepest intimacy to one's spouse.

That it is nonogamy rather than the family per se that is being protected is shown by the general refusal of American law to grant testimonial privileges to persons standing in a kinship relation to one another. Kinship, at least in a culture like our own, is relatively easy to estabhish, so the explanation for the refusal cannot he in the difficulties of verifying the requisite status. ${ }^{58}$ Some courts have, it should be noted, recently recognized-or called into being-a "parent-child"

cal research, sparked by Smith-Rosenberg, The Female World of Love and Ritual: Relations Beiween Women in Nineteenth-Century America, 1 SIGNS 1 (1975).

There is less systematic study of male friendship patterns, but what exists seems to corroborate Rubin's suggestion above. Thus Daniel Levinson and his associates, who have done what is thus far the major examination of the male life cycle, reported the tentative finding that "close friendship with a man or woman is rarely experienced by American men." D. LEviNSON, THE Seasons of a Man's Life 335 (1978). See also C. Gilligan, In a Different Voice: PsychoLOGICAL THEORY AND WOMEN's DEVELOPMENT 152-55 (1982) (for nuales relationships "play a relatively subordinate role in the individual drama of adult development."). A sensitive journalistic meditation on friendship among males is Leonard, Private Lives, N.Y. Times, Mar. 28, 1979, at C!16, col. 2. As with so many other issues of social policy, one wonders what our priorities might be regarding the protection of intimate relationships if women dominated the pohtical process to the same extent that inen now do.

58. A number of other legal systems apparently recognize what might be termed a "kinship privilege." See Coburn, Parent-Child Communications: Spare the Privilege and Spoil the Child, 74 Dick. L. Rev: 559, 600 n.5 (1970) (quoting Cominent, The Privilege Against Self-Incrimination in Anglo-American and Jewish Law, 5 AM. J. CoMp. L. 115 (1956)); Quick, Self-Incrimination Under the Uniform Rules of Evidence, 3 WAYNE L. REv. 1, 5 (1956) (referring to a "continental privilcge" regarding family menbers); Note, The Husband-Wife Privilege of Testimonial Non-Disclosure, 56 Nw. U.L. Rev. 208, 210 n.16 (1961) (French Civil Code). 
privilege. ${ }^{59}$ The thirty-two page opinion by Judge Claiborne in In re Agosto, ${ }^{60}$ the most recent such case, illustrates at least part of the problem presented by such privileges. Judge Claiborne eloquently defends the propriety of such a privilege in terms of values of intimacy and privacy, but offers no explanation of why those values stop at the parent-child relationship. Indeed, I dare say that nost readers of this article do not, for better or worse, have such close relationships with their parents or children that intimate details of their respective lives are often exchanged. One may, to be sure, be particularly bothered by the possibility of a child or parent called upon to testify against one another, but one then has to ask why the same sorts of concerns do not arise when best friends or lovers are asked to testify in similar situations. Simply to say that the family is "special" scarcely suffices as a full-scale argument.

If one adopts the Wigmore test for the award of a privilege, ${ }^{61}$ so that no privilege exists absent a finding that persons would otherwise be less likely to establish a socially desirable relationship, it becomes surprisingly difficult to defend the parent-child privilege. "Indeed," Richard Leinpert has written, "one can find lere a basis for distinguishing spouses from siblings or children since blood relationship[s] have an inevitability and permanence to them that does not attach to relationships based on love and/or mutual imterest. Thus a privilege is not needed to foster the latter relationships." 62 One might well wish to reject this kind of callow utilitarianism, but that impulse still does not explaim why one stops at any given point. Lempert, in a powerful defense of the traditional rule allowing a spouse to bar adverse testimony, refers to the "sanctity of marriages, whatever interest we have in their preservation, and the anguish of the spouse who testifies." 63 Without

59. In re Agosto, 553 F. Supp. 1298, 1325 (D. Nev. 1983); People v. Fitzgerald, 101 Misc. 2d 712, 716, 422 N.Y.S.2d 309, 313 (1979); In re A and M, 61 A.D.2d 426, 435, 403 N.Y.S.2d 375, 381 (1978); see generally Coburn, supra note 58; Kandoian, supra note 13; Kaplan, Mason Ladd and Interesting Evidence Cases, 66 Iowa L. Rev. 931, 944-47 (1981) (discussion of People v. Fitzgerald); Comment, The Child-Parent Privilege: A Proposal, 47 Fordham L. Rev. 771 (1979).

60. 553 F. Supp. 1298 (D. Nev. 1983).

61. See supra note 37 and accompanying text.

62. Letter from Richard Lempert to the author (Sept. 1, 1983) (copy on file at the Duke Law Journal). I should make clear that Lempert, who prefers "imdividual integrity-privacy justifications for privileges," does not personally endorse the Wigmore rationale.

63. Lempert, A Right to Every Woman's Evidence, 66 IowA L. Rev. 725, 736 (1981). In soine states, the spousal privilege may be asserted both by the witness-spouse and by the adversely affected nonwitness-spouse. This means that one spouse can prevent the other from testifying even if the other's decision to testify is voluntary. The Supreme Court endorsed this as a federal evidentiary rule in a 1958 decision, Hawkins v. United States, 358 U.S. 74 (1958), in which it stated that "the law should not force or encourage testimony which might alienate husband and wife, or further inflame existing domestic differences." Id. at 79 (emphasis added). Hawkins was 


\section{wishing to disparage his "sentiments," 64 I am still compelled to ques-}

specifically overruled in 1980. Tramınel v. United States, 445 U.S. 40 (1980). Chief Justice Burger, writing for an eight-1nan inajority, pointed out that the willingness of a spouse to testify adversely against a mate indicates that

their relationship is almost certainly in disrepair; there is probably little in the way of inarital harmony for the privilege to preserve. In these circumstances, a rule of evidence that permits an accused to prevent adverse spousal testinony seeins far more likely to frustrate justice than to foster family peace.

445 U.S. at 52 . The privilege was retained only insofar as "the witness spouse alone [nay] . . . refuse to testify adversely; the witness may be neither compelled to testify nor foreclosed from testifying." Id. at 53. This rule, said the Court, "furthers the inportant public interest in marital harmony without unduly burdening legitinate law enforcement needs." Id.

The key term in the Trammel analysis is "voluntary." Thus Richard Lempert opposes the Court's decision in Trammel on the ground that it evades recognition of the reality of the plea bargaining process, in which the State offers one spouse a good deal in order to create a willingness to testify against the other. Lempert, supra, at 734. The government had given Ms. Trammel, who lad been a partner in crine with her husband, imenunity in regard to her own testimony and further advised her that cooperation would be rewarded by reducing her charge to a misdemeanor for which she would receive probation. "Ms. Trammel nay have testified willingly in a certain sense, for the facts give us every reason to believe that she preferred seeing her husband in prison to being there herself." Id. But, Leinpert says, this notion of voluntariness would apply equally in the Hawkins case, in which Ms. Hawkins had been held as a material witness prior to her agreement to testify. "[S] he obviously found an agreeinent to testify against her husband more congenial than rotting in jail. In neither case would I call the testimony voluntary." Id.

What the traditional adverse testimony rule boils down to, says Lempert, is "that the government cannot destroy the marital relationship, the way it would the relationship of ordinary coconspirators, by emphasizing confiicting interests and allowing one guilty party to promote her well-being by turnimg in the other." Id. at 735 . Lempert does not think that "the state has any business turning one spouse against the other, even if it might advantage the spouse who has turned." Id.

The issue between Lempert and Chief Justice Burger raises a criminal-procedure version of the "state action" dilemina. We differentiate, in enforcing the exclusionary rule, between evidence that was seized illegally by the State and illegally seized evidence that nonetheless came into the hands of the State legally. Similarly, there is good reason to mark the difference between nefariously gotten spousal testimony and spousal testinony that the State has innocently coine by. One might agree with Lempert's overall argument against Trammel on its facts, but still oppose a rule of evidence that prohibits even genumely voluntary betrayal, especially if the reason for the betrayal stems froni a perception that the spouse is a public eneiny.

If, on the other hand, one accepts the Trammel analysis, then one unust recognize that its logic dictates allowing a spouse to divulge even confidential communications so long as the testimony is genuinely voluntary. After all, we do not prohibit ex-spouses from writing memoirs disclosing the most intimate details about their former partners. It might be noted, though, that English law, much less enamored of freedom of the press, does allow injunctions to be granted against books with unseenly invasions of the privacy of the ex-spouse. See Duchess of Argyll v. Duke of Argyll, 2 W.L.R. 790 (Ch. 1965). Unless one advocates a similar rule for the United States, it is difficult to see why such testimony, made available to the "court of public opinion," ought not be available to ordinary courts as well.

It should be clear, in any case, that there is a significant difference between protecting relationships and granting a stronger, more general power to a defendant to prevent certain testimony from passing the lips of those she had trusted. The strong privilege can be defended on either of two grounds: (a) the einphasis on self-protection, see supra notes 19-23 and accompanying text, or (b) an einpirical argument that, given the State's readiness to induce betrayal, the only way to protect intimacy is to grant the strong privilege. The weaker privilege, which the witness spouse alone inay assert, rests, on the other hand, solely on the recognition of the value of intimacy itself. Whether one committed to the value of intimacy will opt for the stronger, rather than the weaker, 
tion the legitimacy of focusing only on spousal interests and anguish to the exclusion of the interests and anguish of friends and lovers.

\section{Privileges and Liberal Neutrality.}

By this point I hope it has becoune clear that the issue of testimonial privileges implicates one of the central questions of contemporary liberal political theory: Can the State be truly neutral among hife plans? Ronald Dworkin, aunong others, has defined liberalisnı as consisting precisely in the State's refusal to define the good life for its citizens. ${ }^{65}$ Yet it is impossible to imagine a coherent theory of testimonial privileges that does not at the saine time enunciate sonie notion of the good life, whetlier "good life" is defined as one including tlie blessed state of inatrimony, close friendship, or frequent consultations with one's psychiatrist. That is, of course, as true of this essay as of any other defense of any given privileges. Tell ne the privileges you wish the State to adopt, and I will tell you (at least soinething about) your vision of the good life.

There is, then, no escape froin the coniplex problenis of social and political theory presented by any attempt to make the testimonial privileges cohere. Each of the present privileges can be explained historically or sociologically, but this is obviously different from defending them theoretically as "fitting" within an overall rationale. What might we do other than return the topic to its present place within tlie shadows of our concerns?

One way of inaking the structure of privileges cohere is simply to abolish almost all of them, limiting retention to those in whicli the problent of fit is least present. Major candidates under this latter category would include the lawyer-client privilege ${ }^{66}$ and the confessional

version of the privilege will depend upon the degree of plausibility found in (b), the empirical argument.

64. Id. at 737.

65. See Dworkin, Liberalism, in Public \& Private Morality 113, 127 (S. Hampshire ed. 1978). Dworkin appears to back off somewhat from this position in Dworkin, What Liberalism Isn't, N.Y. REv. OF Books Jan. 20, 1983, at 47 (reviewing B. ACKeRMAN, Social Justice AND THE LiBERAI STATE (1980)). Ackerman bnilds his own theory around the notion of State neutrality, and this theme is pervasive in contemporary liberahsm, uniting sucl otherwise disparate figures as John Rawls, Robert Nozick, and Friedrich von Hayek. See 2 F. vON HAYEK, LAW, Legislation and Liberty 1-5, 108-11 (1976); R. Nozick, ANarchy, State and Utopia 33, $271-74$ (1974); J. RAWLS, A THEORY OF JuSTICE passim (1971).

66. Even though there is little problem with "fit," insofar as society has provided a clear test as to who counts as a lawyer, one might still question this social bolstering of the power of licensed lawyers in our society. See, e.g., M. Friedman, CAPITAlism and Freedom 137-60 (1962). 
relationship between ordained priests and penitents. 67 Aside from these, however, the State would offer no privileges at all, because of the lack of a theoretically defensible rationale for deciding on their allocation.

The other polar alternative is also possible, of course: We could simply accept as dispositive the refusal by any potential witness to testify about confidential communications-or to testify adversely at allsimply by asserting that the giving of such testimony would betray an important private relationship. Similarly, one inight allow the person potentially aggrieved by the witness' testimony to object on the ground that he had considered the witness to be a close personal friend and had therefore taken the witness into his confidence. A Mafia-connected lawyer, of course, would be entitled to claim the privilege against disclosing conversations with his clients; we could extend the same privileges to others connected with the Don, as well as to the potentiallybetrayed Don himself.

I assume, lowever, that no reader finds a carte blanche friendship privilege even reniotely plausible. We do wish to maintain some capacity for the collective social order to garner evidence against those who break its laws. If one is entitled to purchase invuhrerability to forced disclosure merely by prefacing a remark with "Confidentially, and I'm telling you this only because you're a good friend (like the two hundred other close friends I've told this to)," or by invoking one's distress at another's betrayal of a putatively intimate relationship, conviction of criminals would become markedly nore difficult.

\section{A Modest Proposal}

\section{A. Privilege Tickets.}

I assume that neither of the polar solutions described above is appealing to inost readers. The first is too Draconian; the second is wildly antisocial in the most fundamental sense of that term. Thus I offer the following alternative. It is predicated on the view that the State should define as minimally as possible, if at all, those who are entitled to play a role as our confidantes. A free society that purports to be neutral among life plans—or, to use a less philosophical jargon, "life styles"ought to leave in the hands of its citizens decisions as to who their intimates shall be. I should emphasize that the following alternative is

67. I put aside the potential constitutional problem with such de facto selecting-out of the Roman Catholic confessional for a protection that would be unavailable to most other denominations. See generally Stoyles, The Dilemma of the Priest-Penitent Privilege-The Application of the Religion Clauses, 20 U. PITT. L. REv. 27 (1967). 
offered as a thought experiment rather than a fully serious suggestion for legislation, although I hope it is no less useful on that account.

Imagme a society that assigns to each of its members an equal number - say twenty to thirty-of "privilege tickets," which could be distributed to those with whom a person wished to assure a relationship that could not be vulnerable to State intervention and forced testimomal disclosure. The privilege-ticket plan responds to the basic problem that there is no empirical test by which to distinguish relationships worth protecting from those that are not. Insofar as tests are present, they are probably inore plausible concerning agency relationships, assuming that it makes sense to say that one is best advised to seek legal advice from a lawyer or inedical advice froin a doctor. But surely no tests can readily be suggested that delimit the range of imtimate relations, unless one seriously suggests that only legal spouses should enjoy protection. The privilege-ticket plan allows each of us to pick those relationships that are most central to us and concomitantly requires the State to recognize the privileged status of those relationships. Should you wish to talk imtimately with your local bartender or hairdresser, you would only have to give him one of your privilege tickets.

That, in bare outline, is the thought experiment. Now let us look at some of the problems, aside from political practicality. First, under the proposed scheme, the recipient would have the option of accepting or rejecting a ticket. The "bartender," after all, might be an undercover agent trymg to ferret out the information that you are giving under the misapprehension that the "bartender" really is a bartender. Only if a person accepts the ticket can one liave full confidence that one's conversation is invulnerable against forced disclosure. ${ }^{68}$

Second, assuming that it is $A$ who has given a ticket to $B$, only $A$ 's statements would be protected. For $B$ to be protected as well, there

68. Although nothing depends upon this, I will assume that a privilege ticket creates in the donee a right to refuse to testify against his donor but that the donor has no right to prevent the donee from testifying if the donee so chooses. Thus, the world I imagine is one in which no empirical argunent drives defenders of intimacy to embrace the strong testimonial privilege that would allow the donor to silence his donee. See supra note 63.

One problem with using the weaker notion of privilege is that it would render nugatory the value of a ticket accepted by the "bartender"-undercover agent, for the weak privilege offers no protection against the voluntary decision of the agent to testify about one's secrets. One response to this problem, which I favor, is to regard it as an independent violation of due process to allow State agents to engage in such inasquerades. In such situations, it is the State itself which is betraying by infiltrating the private lives of its citizens through the false pretense of its agents. This I regard as fundainentally objectionable in a way that taking advantage of truly voluntary decisions by ex-confidantes to turn on their former intimates is not. See generally Levinson, supra note 30 . 
would have to be reciprocal exchange. In the absence of such exchange, $A$ would be protected against $B$ 's forced disclosure that $A$ had said, "I einbezzled the inoney," but $B$ would not be protected against $A$ 's necessity to testify that $B$ had stated, "I've done some things I'n not too proud of myself, such as stock fraud."

The limited number of tickets raises two problems: replaceability and alienability. By definition, the notion of "limited" means that there will be fewer tickets available than any given individual might like. Should you hand them out promiscuously and then discover that you have changed your set of friends, you would have no further tickets to hand out. 69 Even if this fact might assure that you took great care in deciding whom to give a ticket to, it would still not respond fully to the possibility of personal tragedy. One's closest friends might, for example, be wiped out in an accident; in this imstance, a certain number of replacement tickets might be allowed. Alternatively, the tickets might be handed out over time, so that one would get ten on one's twentieth birthday, ten more on one's thirty-fifth, and the final clutch of tickets on turning fifty. This distribution scheme is obviously more paternahistic than handing them out all at once, but we will let that pass.

Handing out an equal number of tickets seems to reflect an assumption that all persons have an equal propensity for intimacy. There is, of course, no reason to believe this, and thus one might suggest that the tickets be alienable in order to allow those with less desire for intimate relationships to sell their confidentiality entitlements to those with greater desire. My response is simply that, whatever scheme of distribution might be desirable in the best of worlds, ${ }^{70}$ tickets should not be ahenable in the distinctly imperfect society in which we live. If there is any one good that should not be subject in any degree to the vagaries of market inequahity, it is the enjoyment of intimate relationships and whatever solace they bring.

\section{B. Objections and Replies.}

I suspect that most readers will greet this thought cxperiment with absolute disbehef, if not ridicule. I thus turn to some objections. I seek not only to provide some tentative answers to the objections, but also to

69. Robert Nozick, in private communication, has suggested that one potential solution to the replaceability problein is to allow a person to reclain her ticket, but only after the passage of, say, a year. This would assure that one could not make every conversation confidential by hand. ing the ticket out at the beginning and reclaining it at the end, while taking note at the same time that most of us in fact change our close friendships over time. Even under this modification, it should be noted, the inaximum number of completely protected relationships at any one time is equal to the number of privilege tickets. Nozick would also support the alienability of tickets, although I reject this notion. See infra text accompanying note 70 .

70. Indeed, in the truly best of all worlds, we would not need sucl things as privilege tickets. 
suggest that our responses to the experiment provide illumination about the intersection of (public) law and (private) consciousness. This area of law truly forces us to think about what we might prefer to remain unthinkable and unthought.

Two arguments must be ruled out immediately. First, to the complaint that the privilege-ticket plan allows the State, in soine manner, to define the structure of our intinnate relationships, the response is that that is precisely what the State does now. It is, after all, the State that has declared, through assignment of testimonial privileges, that relationships with a legal spouse or certified psychiatrist are "more valuable" than those with a lover, compassionate friend, or brother. Only if one thinks that the present network of privileges is in some sense "natural" can it be seriously objected that the suggested scheine recognizes an authority in the State that is otherwise lacking.

Nor can it be argued, secondly, that the plan is unadministrable, at least technically. Modern computers can easily be programmed to handle a central registry of privilege tickets. Surely a country that can support a system of national banking or airline reservations can solve any technical problems of administration of privilege tickets. Requiring registration also mitigates the problem, for example, of a criminal's thrusting a privilege ticket into the confederate's hands just before the commission of a crime. Indeed, the State might well decree that no ticket is valid until some period of time, whether thirty days or nine months, after its issuance by the individual. This waiting period would serve to discourage one's ticketing another not out of concern for the inherent quality of the relationship but rather because of the specific information being revealed and the potential for harm if it were ever disclosed to the authorities.

There is, of course, an incursion on privacy in requiring public registration, ${ }^{71}$ but this seems little greater than the similar incursion involved in having to purchase a marriage license. Still, one might object that this would still give the State entree into the intimate lives of its citizenry simply by looking up the lists. This objection rests on the presumption that the State could not itself be trusted to obey laws prohibiting such inspection, a presumption that is perhaps altogetler too plausible. Even here, though, there inay be a relatively easy answer, which is to make the tickets, like personal checks or bearer bonds,

71. "Public" could become a word of art, for the duty to register does not entail that the information is open to publie view. Consider the confidentiality accorded to income-tax returns, for example, despite the fact that they are obviously "public" documents that we are required to fill out. See I.R.C. $\S 6103$ (1976). 
effective upon being filled in and dated by the holder of the ticket. Presumably such filled-in tickets could be kept in safety-deposit boxes, like other valuables, ready to be produced when needed. In any case, I am confident that all technical administrative objections can be answered.

There are three other objections, however, which are significantly weightier. The first is what might be labeled the "crime-control" objection: adoption of the scheine would make it even harder for society to find and punish criminals, particularly if the scheme were unaccompanied by changes in fifth ainendinent doctrine, which would make it easier to ask suspects directly if they had done certain deeds. Probably the most pithy statement of the crime-control argument is Bentham's, in his attack on the prohibition of adverse spousal testimiony:

[If] a man could not carry on schemes of mjustice, without being in danger, every moment, of being disturbed in them,-and (if that were not . . . enough) betrayed and exposed to punishment,-by his wife; injustice in all its shapes, and with it the suits and the fees of which it is prolific, would, in comparison of what it is at present, be rare. ${ }^{72}$

This emphasis on the policy of preventing crime, however, simply reflects an unwillingness to take seriously the professed importance of privacy and protection of intimate relationships.

If one is persuaded by Fried and others ${ }^{73}$ of the essential connection between notions of personhood and protection against forced disclosure of intimate exchange or adverse testimony, then the added amount of social utility arguably available through greater ability to locate and convict the guilty simply will have to be sacrificed. Otherwise, we can scarcely be said to be taking a "inost fundamental human riglit, that of privacy," 74 witlı any great seriousness.

Granted, this affirmation of the importance of privacy rights pales a bit in light of iny restriction of the number of privilege tickets to the

72. $5 \mathrm{~J}$. Bentham, Rationale of Judicial Evidence 339-40, quoted in $8 \mathrm{~J}$. Wigmore, supra note $37, \S 2228$, at 218 .

73. See supra note 38 .

74. Kewanee Oil Co. v. Bicron Corp., 416 U.S. 470,487 (1974). The Supreme Court, in an opinion written by Chief Justice Burger, there upheld the validity of Ohio's trade secret law against the claim that it was preempted by the Constitution's commitment of patents to the national government. In addition to the comment quoted in the text, the Court also took note of the "inevitable cost to the basic decency of society when one firm steals from another." Id. One wishes that the Chief Justice and some of his colleagues were as sensitive to such costs in the context of the government's use of informers to intrude into-and "steal" information from-the private lives of citizens. Compare, e.g., United States v. White, 401 U.S. 745, 748-54 (1971) (plurality opinion) (" $[\mathrm{A}]$ police agent who conceals his police connections may . . . testify concerning [his conversations with a defendant] . . . without a warrant authorizing his encounters . . . and without otherwise violating the [defendant's] Fourth Amendinent rights.") (citing Hoffa v. United States, 385 U.S. 293 (1966)), with Levinson, supra note 30. 
relatively small number of twenty or thirty. Presumably it is our commitment to some kind of crime-control policy that limits our willingness to give every individual an unlimited supply of privilege tickets. This last point, moreover, brings up as well the difficulty of figuring out what it means to take seriously certain rights, such as the right to private relationships of friendship and love, in a world in whicls we have identities as public citizens.

The second nnajor objection is drawn from what is essentially a rational-choice model of calculation. It attacks the premise that the privilege-ticket scheme would increase the realm of genuine private freedom. It may be true, this arguinent runs, that there is a superficial increase in the number of relationships accorded absolute protectionfrom, say, one (spouse) to twenty (lovers, friends, etc.) - but what this leaves out is the present ability to purchase a certain amount of protection agaimst betrayal by invoking the 1noral obligations of friendship. That is, if one has forty friends, all of whom will know at least one damaging secret, it is at least conceivable that all will refuse to betray that secret, either by committing perjury or even by a willingness to go to jail for contempt of court. Even if the probability is only one in four for any given person, this would still predict that at any given time there would be ten people-in addition to those protected by existing privileges-who would be unwilling to tell the secret. If, on the other hand, one has only twenty tickets to distribute over a lifetime, lialf of them would have to have been distributed to get the same level of protection.

In addition, though, the very fact that privilege tickets were known to be available, but unused, might decrease the felt obligations of friendship on the part of those to whom tickets were not distributed. It would not be surprising if someone tliought, "Wliy should I risk jail for someone who doesn't even feel close enough to me to give me lier privilege ticket?" The answer to this question-"I knew I could count on you, so I saved my tickets to use only with persons who won't stay with me through thick-and-thin"--gives new meaning to the old adage that with friends like these one needs no enemies. ${ }^{75}$ Why would a genuine

75. My colleague William Powers has emphasized the quintessentially self-protective nature of this response, since it seems to rest on the assumption that the whole rationale of the privilege ticket is protection of the individual from possible "betrayal." However flattering the statement may be that $A$ views you as someone who will be steadfast even without a ticket, this also necessarily means that $A$ contemplates with equaninity the possibility that you will go to jail as the price of silence, even though this possibility would be foreclosed had he given you one of his tickcts. $A$ is thus only minimally interested in the relationship and not at all interested im your welfare. He is an egoist interested only in maximizing his opportunities for self-defense. Why, indeed, ought you risk your own interests to protect someone like that? 
lover or friend require her confidante to choose between lying and going to jail when protection against such a dilemma is readily available via the ticket?

We might debate the empirical accuracy of these predicted behaviors and the assertion that one might have a greater amount of protection under the present regime of law than under the privilege-ticket plan. It is clear, though, that the major question under this objection involves only the quantity of actual protection likely to be given. Presumably this objector would switch if convinced that the privilege tickets would in fact supply inore protection, just as the proponent of the plan would withdraw it if the facts appeared otherwise.

A variant of this second objection, insofar as it too rests on a rational-actor model of behavior, emphasizes the motivation of the person handing out the tickets. I have been assuming throughout my argument that people are genuinely concerned with protecting their imtimate relationships with friends, lovers, or family. But of course it is altogether possible that a rational calculator will hand the tickets out to crimmal confederates or, in any case, to those persons who score highest on a mixture of knowlcdge of sensitive mformation and likelihood of testifymg without the ticket. This argument is joined with the first one above insofar as it suggests that the society would give up great resources of crime control and gain relatively little protection of genuine intimacy.

If one beheves in the prevalence of such rational actors in our society, then perhaps the objection is successful, for the purpose of the privilege-ticket plan would indeed be stood on its head if the plan's sole effect were to protect only marginally important or downright antisocial relationships. Again, to some extent this is an empirical question, although it suggests how genuinely unfortunate the widespread adoption of such notions of "rationality" would be. The decent would be deprived of an important protection solely because of our fears that the indecent would abuse the purposes of the plan.

A third objection, however, is radically different from the two outlined above, for it points to the added tensions and anxieties of everyday life that could be generated if the plan were adopted. ${ }^{76}$ That is, the

76. My approach here is deeply indebted to the work of Erving Goffman, particularly to Relations IN PUBLIC (1971) and Frame ANALYSIS: AN ESSAY ON THE ORGANIZATION OF EXPERIENCE (1974). Goffman, through an extremely close analysis of everyday life, makes the reader aware of inany of the tacit assumptions we use to "frame" otherwise disordered experience and thus get through another day. To become self-conscious about these assumptions or conventions is to realize how vulnerable we are to others who are able to use their knowledge of the conventions as a weapon against us. We may have such peace of mind as we do only because we do not ordinary achieve-or even strive toward-the kind of self-consciousness that Goffman exhibits. 
ultimate effect of adopting the plan would be the creation of yet another "marker" by which people could signify the level of their relationships. It would quickly enter into the whole web of cultural possibilities and the language of social meaning. Just as the decision to use the second person singular has great meaning in cultures with a language that makes this embleinatic of a closer relationship-and, of course, this decision is hiterally unavailable in English-speaking cultures-the decision to give or receive a ticket would become freiglited with import: "If you really love me, prove it by giving me one of your privilege tickets." 77

The additional "freedom" allowed by the privilege-ticket plan would be illusory. It would be more than offset by the discontent attendant on its private administration. The present scheme, problematic as it may be, has the virtue of not encouraging constant calibration of the levels of one's relationships. To paraphrase a remark once inade by Philip Rieff, in life all things are possible, but it is the function of culture to limit possibility by making certain actions unthinkable. ${ }^{78}$ The most powerful examples are the interdictory taboos, sucls as incest. Our current testiniomal privilege schema is not interdictory, but our very refusal to think seriously about its rationale guarantees that there will be one less thing to be anxious about in our relationships with people. To think constantly about the exact level of individual relationships would be a freedom that many of us inight well not wish to have. Indeed, "friendship" itself might even be diminished as a result of the additional recognition that it is not a "natural" status, but instead the product of specific cultures and ways of life that are capable of transformation. ${ }^{79}$

This last argument is profoundly conservative, and it does not accord very well with a world that is as open to transformation as ours appears to be. We have allowed the social meaning of "marriage" to be drastically transformed by the consciousness of the easy availability of divorce. There seem to be few principled arguments in favor of refusing to subject all aspects of our lives to rational investigation; it has been said, after all, that the unexamined life is not wortl living, even if

77. Robert Nozick has suggested that it might be appropriate for a person publicly to announce that he will not dispense any of his tickets-indeed, perhaps he inight publicly burn them-so that no one not offered a ticket could feel rebuffed, at least not relative to any other friend of the "refusenik."

78. Rieff has also observed that "[t]he predicate of sociological analyses of the moral should be that 'Man,' the most capacious of ideal types, is capable of everything. That predicate, the possibility of action without himit, must lead sociological analyses to imsights that are defensive, against the very predicate of its special understanding." P. RIEFF, FELLOW TEACHERS 21 (1973).

79. See R. BRAIN, Friends AND Lovers, passim (1976). 
the examination teaches only how radically contingent are some of our most basic social institutions. 80

In any case, I hope I have deinonstrated that the seemingly technical problems of testimonial privilege involve issues that lie at the center of the contemporary debate about the foundations of hberal society. To privilege certam relationships is to declare certain values; but these values, once openly declared, impose demands of consistency upon the social practices in which they are first discovered. The problein of "fit" exists because consistency is not the only demand that we have made upon our existing scheme of privileges. The privilege ticket fantasy has, if nothing else, teased out some of these other, more hidden demands. In particular, we are coinpelled to recognize our collective demand that the social order restrict the overwhelming universe of interpersonal possibility, and that it present this restriction to us disguised as "nature." These demands go some way toward explaming why our law allows each of us but a simgle, spousal privilege ticket. But, more importantly, they raise questions that go to the heart of our entire conception of huinan selfhood and the relationship between the person and the social order. This last phrase is purposely ambiguous, for it points both to the extent to which the "individual" is at least in part a social creation, and to the inore orthodox problem of the relationship between that "individual"-and her private structures of intimacy-and the State.

80. Janet Malcolm valuably reminds us that "the examined life is impossible to live for more than a few moments at a time." J. Malcolm, IN the Freud Archives 25 (1983). We tend to resent individuals and institutions that force us too insistently to examine and reexamine our lives. 